This is not the Version of Record. For more information on Nancheva, Nevena (2019) 'Bacillus Bulgaricus' : the breeding of national pride. In: Ichijo, Atsuko, Johannes, Venetia and Ranta, Ronald, (eds.) The The emergence of national food : the dynamics of food and nationalism. London, U.K. : Bloomsbury Academic. pp. 61-72. see https://www.bloomsbury.com/uk/the-emergence-of-national-food-9781350074132/ 


\title{
Chapter
}

\section{Bacillus Bulgaricus: The Breeding of National Pride}

\author{
Nevena Nancheva, Kingston University London
}

This chapter is a case study of Bulgarian food nationalism with a focus on yogurt (kiselo mlyako), exploring the nationalisation of a staple food which has been produced and consumed in and around the Balkan region for centuries. The chapter references the social construction of yoghurt as a uniquely Bulgarian product, from the 1905 study that discovered the particular subspecies of the lactic acid producing bacteria carrying the national reference (bulgaricus), to the patenting of the product under the Bulgarian National Standard (BDS) since 1971 and its nationally controlled exports. The aim of the chapter is to explore the process of this nationalization, demonstrating that the Bulgarisation of yoghurt is linked to specific economic, political and cultural agendas whose pursuit is impossible unless yoghurt is seen as ethno-nationally authentic. The interrogation of yoghurt's Bulgarian-ness in this chapter engages with the mythical construction of yoghurt as an inherently national product challenging the most prominent ethno-national myths sustaining it: the myth of yoghurt as quintessentially Bulgarian food staple, the myth of yoghurt as ethno-nationally specific to Bulgarian producers, and the myth of yoghurt as representative of Bulgarian-ness and Bulgarian authenticity abroad.

Key words: National food, national identity, yoghurt, authenticity, nationalism

How can bacteria become the object of national pride? Plain Bulgarian yoghurt holds the answer. Available folkloric and historical evidence (references to the local Thracians and their yoghurts in Herodotus and Virgil, among others) suggests that the people living in and around what today is the territory of the Republic of Bulgaria have, since nomadic times, been preparing and consuming a peculiar dairy product: a plain type of fermented milk with grainy texture and distinctive sour taste, prepared by boiling the milk (sheep's but also buffalo's, cow's, goat's) and adding a starter culture (a small amount of lactic-producing bacterial culture preserved in advance). The product has been known and referred to commonly with its descriptive name, sounding similar in most Slavic languages, translated literally from the Bulgarian as 'soured milk' (кисело мляко - kiselo mlyako). No national denomination is attached to the product in the folkloric and historical references that mention it: indeed, soured milk is a staple food in the region which now includes the territory of Bulgaria, but is not confined to it.

The Bulgarian people and the Bulgarian state, however, proudly tout the product as a traditional 'national' food and take pride in it as an element of Bulgarian national identity (e.g. Chomakov, 1987). How did dairy become a Bulgarian national food: answering this question is the main focus of this chapter. Through a case study on the Bulgarisation of yoghurt, built on the basis of participant observation, interviews, and historical research, the chapter will demonstrate that 'nationalising' a food product does not depend on the way people eat - which arguably is more or less stable over time, territory, and social groups - but is rather linked to projects of nationalism (political, economic, cultural). The national in Bulgarian yoghurt thus appears to be but a discursive social construction contingent upon scientific, economic, and historical vagaries. Fortunately, this does not demand 
from Bulgarians lesser pride in the product: kiselo mlyako is as tasty and healthy as it has always been.

\section{Why yoghurt?}

Bulgarians are very fond of their yoghurt. They eat it regularly, either on its own, in fruity desserts, or in cooked dishes. There is a refreshing summer cold soup made of yoghurt, chopped cucumbers, and herbs: tarator (таратор). Yoghurt with water and salt is a ubiquitous breakfast drink (perhaps also because it doubles as a coveted hangover cure). Yoghurt with crushed garlic is sprinkled over all kinds of vegetable or meat dishes for tenderness and taste. Yoghurt with fruit or honey is the quickest and simplest dessert.

But besides eating it with relish, Bulgarians are also proud of their yoghurt. They are proud because their yoghurt is made by a bacterium which is named after them: Lactobacillus Bulgaricus. This proud recognition is owed to the Bulgarian who examined and identified the bacterial contents of home-made yoghurt from his region at the turn of the 20th century (in 1905 to be precise) and published an article about it while studying medicine in Geneva (Grigoroff, 1905): Dr Stamen Grigorov (1878-1945). The lactic acid producing bacteria, which work in a symbiosis with two other bacteria ${ }^{1}$, apparently only thrive in the climatic conditions of Bulgaria, thus giving Bulgarian yoghurt its specific taste, texture, scent and goodness. Taken up as an object of study by a Nobel prize laureate scientist interested in the reasons for aging, Dr llya Mechnikov (1845-1916), the unique qualities of Bulgarian yoghurt were touted as a source of longevity for much of the 20th century (Borov, 1962; see also Chandan and Kilaram 2006: 45; Foster et al 1957 cited in Breslaw and Kleyn, 1973). Therefore, historical chance and the peculiarities of nature, supplanted by scientific research, have shaped the basis of Bulgarians' sense of pride with their yoghurt.

But there are other foods which carry as many health benefits and are not constructed as national foods: bee honey and honey products (pollen, wax, propolis, etc) are but one example, also quite typical for the Bulgarian climate. So how and why did yoghurt become nationally Bulgarian and an object of national pride? The purpose of the following section is to demonstrate that the Bulgarisation of yoghurt is linked to specific economic, political and cultural agendas. Pursuing them is impossible unless yoghurt is seen as ethno-nationally authentic, besides healthy. This has led to conscious efforts, on behalf of many concerned parties, to cultivate the ethno-national authenticity of yoghurt and to celebrate it as a Bulgarian product: something which has not applied in the same way to other staple foods (such as bee honey, to continue with our example). The following paragraphs will illustrate these efforts with examples showing concerned actors from abroad (foreign dairy producing and processing companies, political agents), local authorities and central government-sponsored actors, as well as parties and organizations vested with personal interest to construct yoghurt as nationally Bulgarian and to celebrate it with pride.

\section{What's Bulgarian about Bulgarian yoghurt?}

There is a quaint village in the Rhodope Mountains in the southern edge of Bulgaria, large for the standards of the region with some 500 houses today, which is well known across China for its name: Momchilovtsi. Since 2008 the Chinese company Bright Dairy \& Food (established 1949), whose boss

\footnotetext{
${ }^{1}$ Streptobacillus and Streptoccus thermophilus.
} 
had discovered the beauty and secrets of Rhodope Mountains on a trip to Bulgaria, has been buying yoghurt cultures from Momchilovtsi, marketing its yoghurt, under the village's name, as 'authentically Bulgarian'. The company holds a $6.9 \%$ share of the Chinese dairy market, with Momchilovtsi yoghurt making $20 \%$ of its operating revenue (Euromonitor International 2014). The company advertises Momchilovtsi yoghurt as a health product coming from ancient Bulgarian traditions of clean life and longevity: it is claimed that the village of Momchilovtsi is full of centenarians!

This is not necessarily true. There were 254 centenarians in Bulgaria in 2016 (as per data from the National Statistical Institute 2016) and they were more or less dispersed across the territory (though Pazardzhik district, including parts of the Rhodope mountain, does have the biggest number). Existing scientific research points to a variety of factors that contribute to longevity, consumption of yoghurt being but incidental. But the lifestyle of the villagers in the Rhodope mountains may be seen to comprise most of the other factors: children born to young healthy mothers; living active lives and working outdoors until advanced age; eating a healthy diet of herbal teas, fruit, vegetables and pulses, with low meat consumption and plenty of dairy. It is unsurprising then that throughout the 20th century European publics have been fascinated, at one point or another, with stories of the long-living villagers of the Bulgarian mountains (e.g. Borov, 1962; Chazanov, 1987). Contemporary research on the health benefits of the kind of yoghurt made in Bulgaria, beyond longevity, continue (e.g. Max Planck's Toyoda et al, 2014).

But what the claims for longevity and health could mean outside the realm of gerontology and medicine, is revealed in a curious fact. Since 2015, a Festival of Yoghurt has taken place in Momchilovtsi under the name Rhodope's Traditions. It is a well-promoted event planned as an annual happening, whose 2017 programme featured a beauty contest, children's drawings competition, folk dance and song, as well as tasting and rating of home-made yoghurts. All of this occurs under the label 'Momchilovtsi' well known to Chinese consumers from the yoghurt drink sold under this name (see company website), as the sponsor and organizer of the event is the same Chinese dairy company Bright Dairy \& Food. 38 Chinese representatives participated in the organization of the event in 2017, assisted by enthusiastic locals: thanks to the cultivated interest in the brand, tourists from China have flooded the village, prompting local residents to start studying Mandarin (Deutsche Welle, 2017)!

The Momchilovtsi Festival of Yoghurt is a clear example of fostering traditions where previously there were none. Bulgarians do not celebrate their yoghurt (or, indeed, their food) at local festivals: those usually follow the Bulgarian ritual calendar based on a mixture of religious and old pagan traditions linked to working the land and herding animals (Stareva 2009). And while the festival does showcase some of these traditions (folk song and dance, or traditional dress, for example), they are put to service a narrowly neoliberal agenda which is at odds with claims of authenticity.

When I looked to find similar celebrations of yoghurt in other Bulgarian regions, I could identify only one other event: the Razgrad Yoghurt Fair and Festival of National Traditions and Art Handcrafts, organized by the Municipality of Razgrad (in the north-eastern part of Bulgaria around the Ludogorie region) every year since 2002. The festival boasts a similar focus and, apparently for the first time, has claimed to be the only festival dedicated to celebrating yoghurt. It features a similar programme as the newly formed Momchilovtsi festival but differs in its ambition to include regional and 
international participants, and is explicitly marketed as an international event. In quite a similar neoliberal fashion, the festival has been conceived as a means to spur local development through celebrating tradition. It has been financed under a European Union regional development preaccession fund (under a 2002-2012 project called 'Razgrad - All the City Is a Stage') and conceptually relies on the re-claiming of Razgrad's place as a lively regional market of yoghurt and dairy (see Katrandzhiev 1940 for illustrations of yoghurt sellers from the Razgrad market). The extensive national media coverage of the event relies heavily on the tradition of yoghurt-making as inherently Bulgarian (and associated images of patterned clay pots for making yoghurt, woven textiles for wrapping and decoration, and the everyday utensils used in rural households of the 19th century), despite the conspicuous absence of ethno-national celebrations of yoghurt in the Bulgarian folk traditions.

Other examples of putting to commercial purposes the health benefits of Bulgarian yoghurt and the cleanliness of 'authentic' Bulgarian rural lifestyles can be found in the years preceding the fall of Communism in 1989. In the 1970s another Asian country, Japan, became fascinated with yoghurt after a member of its political elite (a woman, at that) praised it as a healthy and time-efficient substitute to the traditional Japanese breakfast of boiled rice (Yotova, 2018). At about the same time the Japanese company Meiji (established 1906) came into contact with the Bulgarian (then state-led) producer of yoghurt Serdika Sofia at the 1970 World Fair in Osaka. Meiji managed to negotiate with the Bulgarian state permission to use the geographical denomination ('Meiji Bulgaria Yoghurt') in 1973, under the condition that pure cultures and approved technology will be followed in the Japanbased production of yoghurt. Blending together existing scientific research and carefully selected ethnographic images in its branding strategy, Meiji Bulgaria Yoghurt established itself as a market leader in Japan (currently holding $43.7 \%$ of the market according to company data) (for a fascinating case study of the strategy, see Yotova, 2018). The interest of the Japanese and the growing popularity of Bulgarian yoghurt in Japan has, in quite a similar fashion as with the recent Chinese enterprise, stirred vivid interest in the customs and traditions of Bulgaria as the 'real' birth land of yoghurt. For over 40 years now, Bulgarian yoghurt in Japan has held the place of a scientifically proven, authentic health product associated with the longevity of traditional Bulgarian lifestyles. This image has survived the political changes in Bulgaria (the replacement of the communist regime with democratic government in 1989), preserving the trade relationship to this day.

A similar interest in the commercial significance of yoghurt can be identified among local, Bulgarian actors. Fostering awareness of yoghurt as inherently linked to the ethno-national traditions of Bulgaria and celebrating it as culturally important carries in itself a plethora of commercial opportunities. These opportunities became readily available in the first decade after the fall of communism when the restrictions of the centrally-managed planned economy were lifted. Celebrating the legacy of the Bulgarian physician Dr Stamen Grigorov who identified the bacterial content of Bulgarian yoghurt appeared as one such opportunity, especially since it had not been explored fully during the years of communism: as educated in Western Europe and serving in the military of the Bulgarian monarchy before communism, Dr Grigorov had not been an ideal candidate for nationalist glorification during the communist regime. Against the background of the postcommunist ideological void and rising entrepreneurial potential of the free market, interested private parties in Bulgaria began to build on his legacy. 
Under the aegis of the Dr Stamen Grigorov Foundation (est. 1995 - see Grigorova, 2005), a carefully selected volume of contributions (edited by the foundation's chair Ms Yuliya Grigorova, a descendant of Dr Grigorov) was published in 2005, showcasing, notably, the 'national selfconsciousness' of the discoverer of Lactobacillus Bulgaricus. The following year, a National Yoghurt Day was organized by the Foundation, for the first time hosted in the village of Studen Izvor (later also in the national capital Sofia). Since 2006, the event has been celebrated annually, in close cooperation with the local municipality Tran (south-western Bulgaria), the state-sponsored company LB Bulgaricus (which, after the fall of communism, had inherited the state yoghurt plant Serdika Sofia and was now in charge of exporting Bulgarian starter cultures abroad), as well as with the Bulgarian Association of Dairy Producers. In 2007, a step further towards consolidating Bulgaria's yoghurt heritage was taken by the Dr Stamen Grigorov Foundation: a Museum of Yoghurt opened doors in the village of Studen Izvor, housed in a small building near the birth home of Dr Grigorov. As expected, the Museum aims to recreate, in its layout and exhibitions, the traditional image of Bulgarian rural authenticity. Without it, the national heritage of yoghurt would not appear plausible.

Besides developing the commercial potential of this heritage at a regional and national level in terms of milk production and processing, travel and tourism, and structural development, the story of $\mathrm{Dr}$ Grigorov's microbiological discovery also has a visible impact on the cultural identity of Bulgarians as Europeans. In the early days of the Bulgarian state, newly independent from the Ottoman Empire (legally in 1908 but factually since 1878), the brightest and most ambitious young people were sent to study and specialize abroad in the most prestigious educational institutions of Europe (the Bulgarian educational establishment had not formed yet). Grigorov was one of these promising young people, and the contribution he made has had an impact of international significance. So, it seems important for the national mythology to showcase his contribution as inherently linked to the Bulgarian national story.

This can be seen in the recollection of his discovery carefully narrated by Ms Grigorova and the media and researchers she has come into contact with: there are no records of Dr Grigorov's talk at the Institute Pasteur in Paris but recollections held in the family (as testified by Ms Grigorova) have been widely shared and have formed the carrying elements of the story we know today (see Stoilova, 2014: 38-45, also Grigorova, 2015). That story has acquired the standing of a national legend. On one of his trips from Bulgaria, Stamen Grigorov had brought from home a traditional clay pot (рукатка - rukatka) containing some home-made yoghurt, which he examined in the microbiological laboratory where he worked in the Medical University of Geneva. He published an article about his discovery and was invited to speak at the Institute Pasteur in Paris by the prominent Dr llya Mechnikov. The main milk curdling bacteria which Grigorov identified for the first time were named Lactobacillus Bulgaricus in his honour. Despite his success and scientific recognition in Europe, Dr Grigorov preferred to return to his home village after completing his studies, and practiced medicine for the benefit of his compatriots, in times of peace and in war (he lived through the two world wars and the couple of regional wars which Bulgaria waged in the first half of the 20th century), to the end of his days in 1945 (see accounts in Stoilova, 2014: 40-1).

Re-told with the inevitable hint of pride, the story of Dr Grigorov and his discovery has become firmly attached to narratives of the Bulgarian-ness of Bulgarian yoghurt, and has shaped the foundation of the claim to national ownership, supplanted by scientific evidence. It has been claimed (Stoilova, 2014; among others) that Lactobacillus Bulgaricus, in its natural habitat, can only thrive in 
the climatic conditions in and around the territory of present-day Bulgaria. When taken abroad, it eventually mutates, thus changing the qualities of the milk curdled with cultures from it. This is why, since the discovery of the bacteria and the interest it stirred in Europe in the first half of the 20th century as an alleged secret to youthfulness and longevity (Stoilova, 2014: 57-81), producers and purveyors of yoghurts abroad have sought to link their products with the geographical denomination Bulgaria by establishing contacts and securing exports of authentic yoghurt cultures.

The name of the lactic acid producing bacterium, as well as its particular residence preferences, are at the root of Bulgaria's claim to ownership of Bulgarian yoghurt. In 2002 at a summit of the World Trade Organization, Bulgarian representatives attempted to protect it as a geographical indication under Article 23 of the Trade-Related Aspects of Intellectual Property Rights Agreement (Stoilova, 2014: 9-10). The claim was, as it happened, unsuccessful, but it illustrates both official and popular positions on the Bulgarian-ness of yoghurt.

It appears from the above that yoghurt has been the object of deliberate attempts to cultivate and showcase authenticity within a carefully curated ethno-national setting. These attempts have sometimes been initiated by the Bulgarian state and its authorities (as the example of the Razgrad municipality suggests), they have been made by private interested parties in Bulgaria (such as the descendent of Dr Grigorov and her associates), and they have sometimes been undertaken by external, non-Bulgarian, parties, with or without collaboration with local actors (the Chinese Bright Dairy \& Food and the municipality of Momchilovtsi, the Japanese Meiji and the Bulgarian Serdika Sofia, later LB Bulgaricus). The claim to ethno-national authenticity has served various political, economic and cultural purposes, both in Bulgaria and beyond, firmly attaching the national denominator 'Bulgarian' to a staple food which has been produced and consumed in and around the region for centuries, regardless of nationhood and statehood. Yet, the myth of Bulgarian-ness has taken root and has become part of Bulgarian national identity iterations when it comes to food. In our interrogation of yoghurt's Bulgarian-ness, this chapter now turns to the mythical construction of yoghurt which sustains these iterations in order to find out who really makes and eats yoghurt, and where.

\section{Debunking the Ethno-National Myths}

In this section, I address three of the most prominent ethno-national myths that have been applied to construct yoghurt as an inherently national product. The first one is the myth of yoghurt as the quintessentially Bulgarian food staple with clear regional denomination. The second is the myth of yoghurt as ethno-nationally specific to Bulgarian producers. And the third is the myth of yoghurt as representative of Bulgarian-ness and Bulgarian authenticity abroad. All three myths were deployed and seen at work in the examples discussed in the section above.

The now legendary village of Student Izvor, from where Dr Grigorov took his samples of home-made yoghurt, lies in a region in Eastern Bulgaria straddled by low mountains, some few kilometres from the border with present-day Serbia. The region is part of the borderlands severely contested in the modern history of the Balkans, object of contention between Serbia and Bulgaria since the establishment of independent Bulgarian statehood in 1878, mostly around the so called Macedonian Question (Roudometoff, 2002). During the 1885 war between Serbia and Bulgaria, for example, one of the Serbian demands was for annexation of the whole region of Tran (among others) as it was allegedly populated by Serbs. Tran is relatively close to what are today Macedonia and Kosovo. It is 
conceivable to imagine that the type of bacteria responsible for the curdling of Bulgarian yoghurt has not followed closely the vagaries of national border disputes and statehood in the region: indeed, throughout the whole region 'kiselo mleko', as Grigorov pronounced it in the typical local Slavic dialect, is a staple food. There are no national myths linked to its cultivation. In a letter to Prof Mechnikov, Grigorov himself is described by his PhD supervisor as a 'Bulgarian Slav' (see Professor Vincent Massol quoted in Stoilova, 2014: 40). This is to support our claim above that the peculiarities of the Bulgarian ownership narratives are not attached to the production and consumption of the food as such, but rather to the myth of its scientific 'discovery'. Thus, the 'nationalisation' of yoghurt is revealed as a process quite independent of the foodways of the locals.

When I asked about good yoghurt while travelling through the Tran region, my guide took me to a monastery nearby, above the village of Gigintsi, which sold buffalo milk products in its little shop, and later to a shop in a bigger village nearby, Breznik, which was apparently well established in the region. Unlike the monastery shop, the latter was an entirely commercial enterprise but, despite its local renown for selling good dairy, it was not distinguished by any commercial markings or branding. It appeared like a regular corner shop but, while I was waiting, several buyers stopped in cars bearing registration plaques from elsewhere: I assumed the shop was a well known local stop. The yoghurt (and cheese) they sold, both at the monastery and in the shop, did not bear any of the seals of authenticity the Bulgarian supermarket buyer is by now accustomed to: 'original granny's recipe'; the 'real yoghurt of old'; 'a guarantee for a completely natural product'; 'home made recipe'; 'the true Bulgarian product'; etc. However, by the time I took them home on a hot summer's day, the lids had 'swollen'. This, as any Bulgarian would tell you, is the true sign of authenticity: since there are no preservatives or stabilizers in the home-made product, it goes sour very quickly (compare with Stoilova, 2014: 87 who explains that commercial production relies on a much more sterile technology). Of course, this also makes it unsuitable for profitable commercial placement (see also interview with Grigorova 2015). This is to suggest that the 'authenticity' marketed as the true Bulgarian product is necessarily different (whether in contents or in production technology) from the food that has become a staple in the region.

Another way in which the Bulgarian-ness of yoghurt can come under question is through exploring the ethno-national origins of both the makers of yoghurt and the milk used for the production of yoghurt for commercial use. In the summer of 2017, following the Bulgarian path of yoghurt, I chose a route that links the mythical Rhodope mountain with another two mountains teeming with Bulgarian legends, the Rila and the Pirin: I drove from Belovo (on the very edge of Rhodope near the Maritsa valley) through Yundola (between Rila and Rhodope) to Gotse Delchev (in Pirin near the border with Greece). This is a well-travelled route popular with lorries and tourists. It leads to several well-known ski resorts, to the Belmeken National Sports Base, as well as to a border check point with Greece. It is a mountainous region traditionally inhabited by sheep herders, and as soon as the road picked up, I noticed it was lined with sellers of home-made dairy (as well as hand-picked berries and honey). Barely a vehicle passed by without stopping to buy from the local produce. But the sellers, often women or accompanied by women, wore the traditional head-covering that distinguished the local Muslim Pomaks from the (traditionally Christian) titular Bulgarians. The region is controversial in Bulgarian nationalist narratives as it is associated with dangerous proximity to the historical nemesis Turkey, the heir of the Ottomans (see Stoyanov, 1998), and cinematically and fictionally re-told stories of forcible conversion and national treason (e.g. the mythical communist-era film Time of Violence, Staikov, 1988). It seemed then that the Bulgarians hurried to 
buy 'real yoghurt' (the sample taken by Grigorov to Geneva was reportedly from sheep's milk) from the very people they often othered as non-Bulgarians or not real Bulgarians (see Stoyanov, 1998 for details on the anti-Pomak campaigns of the final communist decade).

The yoghurt sold commercially in the supermarket chains is also problematically 'Bulgarian'. Several processes of re-structuring in the Bulgarian dairy industry (including privatisation of the big stateowned producer; lack of agricultural subsidies for the milk producers; reduction in the livestocks; low technologisation of the production; fragmentation of the processing industry into more than 250 milk processing companies) led to a gradual increase in the buying price of milk from producers (Kostov, 1998; Georgieva, 2010; also Georgieva, 2015). As a result, it became cheaper to import milk from technically more efficient and better subsidised European producers (prominently Hungary and Germany - Valkanov, 2014), rather than to buy locally. Besides milk, the milk processors admit to widely using milk substitutes (until 2010 when an updated Bulgarian National Standard of yoghurt production codified into legislation disallowed it). Thus the 'authentically Bulgarian' yoghurt appears to contain not much Bulgarian beyond the bacteria carrying the national name. The controversies in the national public space about allowing other producers in Europe since Bulgaria's EU accession in 2007 to freely use the denomination 'Bulgaria' to describe their yoghurt (see domestic legislative proposal on the Law on the Labels and Geographical Indications 2017) thus appear to lose solid ground.

Finally, we come to address the myth of yoghurt as the one authentic Bulgarian product that represents the country abroad. An application of this myth to the international legal framework was at the root of the Bulgarian representatives' claims for protection at the WTO (mentioned above), as well as in heated domestic debates about lifting national legal protection in compliance with EU regulations (Regulation No 1151/2012 - also mentioned in the above paragraph). Besides the two examples with Asian dairy companies using a targeted advertising strategy to market their products in Japan and China, branding traditional clean and healthy lifestyles and ethno-national authenticity, Bulgarian diasporas' consumption abroad offers a good case of the same mythologizing. A forthcoming study carried out in 2017-18 of Bulgarian foodshops and restaurants in the UK (Ranta and Nancheva, 2019 forthcoming) unveiled an interesting dairy product range. Some smaller display fridges in Bulgarian foodshops in the UK featured the familiar range of choice of yoghurt pots which one can find in any corner shop in Bulgaria. But the better developed foodshops featured dairy products which cannot be found widely at home ${ }^{2}$ but nevertheless claimed on their label to be 'authentic'. The national and international certification of quality that these products carry (e.g. under the Bulgarian National Standard or the BRC-IS Global Standard for Food Safety), together with their targeted and consistent branding strategies, have opened for them diaspora markets which consume the products as 'Bulgarian', rather than dairy. But the discovery of these products abroad clearly indicates that their vision of Bulgarian-ness is one carefully crafted and marketed to certain audiences. Just as the fascination of the Chinese and the Japanese with 'authentic' Bulgarian yoghurt led to sponsorship of 'traditional' fairs of the yoghurt and scientific research expounding the longevity benefits of Bulgarian yoghurt, the fascination of Bulgarian diaspora consumers with all good things Bulgarian re-creates a vision of the ethno-national that is not necessarily 'authentic'.

\footnotetext{
${ }^{2}$ Vedrare (established 2008) https://www.facebook.com/vedrare/
} 
This section provided a brief overview of three visible myths applied in the construction of yoghurt as a quintessentially Bulgarian national product: the myth of regionally delineated staple, the myth of ethno-national origin, and the myth of authentic ethno-national representation abroad. It aimed to challenge the construction of Bulgarian-ness that is sustained by narratives mythologizing the ethno-national character of yoghurt. This challenge is not meant to devalue the importance of the construction but to demonstrate its contingent nature. Yoghurt is an important and in many ways unique staple food in the Balkans. But its transformation into a Bulgarian national staple food is due as much to chance, as it is to the demands of political, economic, and cultural agendas.

\section{But what of national pride then?}

I often reflected of my positionality while researching this chapter and writing it: as an ethnic Bulgarian, I speak of national pride in the third person. With a view of my fellow Bulgarian readers, I thought I should cultivate my national heritage rather than question its credibility. And I do like Bulgarian yoghurt: as a matter of fact, I only ever have that (the texture of other yoghurts is different)! Yet, I have argued in this chapter that the Bulgarian-ness of yoghurt should be understood as separate from the production and consumption of yoghurt. While people in the region have always enjoyed yoghurt, they have only comparatively recently started to speak of it as nationally Bulgarian: over the course of the second half of the 20th century, and perhaps more visibly in the years after the fall of communism and the opening up of the previously controlled Bulgarian economy. This Bulgarisation is partially linked to the nationality of the person who examined and identified what turns milk into yoghurt: the main lactic acid producing bacterium officially named Lactobacillus Bulgaricus, discovered in 1905, apparently only thrives in the climate of Bulgaria. But beyond historical and geographical chance, the Bulgarisation of yoghurt is also linked to concrete economic, political and cultural agendas which can only be pursued if yoghurt is understood as 'authentically' Bulgarian.

This desired authenticity is a myth. The lactic bacteria probably have not followed the frequent border changes in the Balkans over the past centuries to choose the territory of Bulgaria, so immediate neighbours such as Serbia and Macedonia could make similarly plausible claims of ownership. Instead, they just enjoy 'kiselo mleko'. Moreover, the product being marketed as authentically Bulgarian nowadays is much different from the one which the eponymous bacteria came from: technologies applied for commercial production and health and safety reasons have changed both its content and qualities. Furthermore, the national authenticity of the product could be challenged both on the grounds of the ethno-national background of its makers (often not titular ethnic Bulgarians) and on the grounds of the origins of its main ingredient - milk (ever more frequently imported from outside Bulgaria). Finally, the yoghurt sold abroad to represent authentic Bulgaria is often especially created for specific audiences (Bulgarian diaspora consumers abroad or foreign consumers) and thus not 'authentic' in the true sense of the word.

Yet, the mythological ethno-national authenticity does not mean there is no reason for pride. Yoghurt is a delicious food with numerous health benefits, linked to Bulgaria and the Balkans in unique ways. Its pre-industrial preparation symbolises the home, land and domesticity: fresh milk from sheep grazing on beautiful mountainous pastures, boiled in a patterned pot and wrapped in red woven textile near the fire. This imagery draws post-industrial consumers looking for clean and healthy living and romanticizing about their national identity in an era of globalization close to their 
traditional heritage. Thus, many young Bulgarian families today have taken to preparing their own yoghurt at home, using certified starter cultures increasingly more widely available on the online market (the demand for these is growing within the rising 'foodie' culture). Defining who they are through what they consume, these new Bulgarians carefully foster an image of themselves as cosmopolitan Europeans in touch with their traditions and conscious of their choices: foodwise and otherwise. This fosters a kind of national identity which transcends the constraints of the ethnonational and is adaptable to a connected world. Traditional home-made yoghurt can become a national business card for such an identity, and this is no small reason for pride.

\section{Bibliography}

Borov, I. (1962) Bulgaria, country of the centenarians. In Journal of Gerontology Vol 10: 392-6. In Italian.

Breslaw, Ellen and Dick Kleyn (1973) 'In Vitro digestability of protein in yoghurt at various stages of processing' in Journal of Food Science 38 (6): 116-1021.

Chandan, Ramesh C. And Arun Kilara (eds.) (2006) Manufacturing Yogurt and Fermented Milks (Blackwell Publishing).

Chazanov, Mathis (1987) Lives without stress: Bulgaria - Land of the Centenarian. In Los Angeles Times of 15th June 1987 available at http://articles.latimes.com/1987-06-15/news/mn4174_1_group-living/2 last accessed 28th Feb 2018.

Chomakov, Hristo (1987) Bulgarian yoghurt: health and longevity (Sofia: Zemizdat).

Deutsche Welle (2017) 'Bulgarian yoghurt drives the Chinese crazy' (from 26th Sep 2017) available online at

http://www.dw.com/bg/\%D0\%B1\%D1\%8A\%D0\%BB\%D0\%B3\%D0\%B0\%D1\%80\%D1\%81\%D0\%BA\%D0 \%BE-\%D0\%BA\%D0\%B8\%D1\%81\%D0\%B5\%D0\%BB\%D0\%BE-

\%D0\%BC\%D0\%BB\%D1\%8F\%D0\%BA\%D0\%BE-

\%D0\%BF\%D0\%BE\%D0\%B4\%D0\%BB\%D1\%83\%D0\%B4\%D1\%8F\%D0\%B2\%D0\%B0-

\%D0\%BA\%D0\%B8\%D1\%82\%D0\%B0\%D0\%B9\%D1\%86\%D0\%B8\%D1\%82\%D0\%B5/a-40686859 last accessed 28th Feb 2018.

Euromonitor International (2014) China Country Report (Packaged Foods) available at http://www.euromonitor.com/china?PageCode $=195 \&$ CountryCode=null\&IndustryCode $=88216 \&$ Con tentType=null\&ReportType=null\&SortBy=1\&PageNumber=0\&PageSize=20\&PageType $=13$ las accessed 26th Mar 2018.

Georgieva, Mara (2010) Milk for sale: milk processors fight a battle for the raw resource. Kapital Newspaper of 24th Sep 2010 available at https://www.capital.bg/biznes/kompanii/2010/09/24/965146_mliako_za_prodan/ last accessed 28th Feb 2018.

Georgieva, Mara (2017) How yoghurt will not be Bulgarian anymore. Kapital Newspaper of 8th Sept 2017 available at https://www.capital.bg/biznes/kompanii/2017/09/08/3037551_kak_kiseloto_mliako_niama_da_e_ bulgarsko/ last accessed 28th Feb 2018. 
Grigoroff, Stamen, 1905. Étude sur une lait fermentée comestible. Le „Kissélo mléko“ de Bulgarie. Revue Médicale de la Suisse Romande. Genève. Georg\&G., Libraires-Éditeurs. Librairie de L’Université.

Grigorova, Yuliya (2005) At the beginning was the memory of home: 10 years since establishment (Sofia: University Publisher St Kliment Ohridsky). In Bulgarian.

Grigorova, Yuliya (2015) Interview for the BTA with Elka Robeva on 9th Jun 2015 available at http://www.bta.bg/bg/video/show/id/0_zcvj8ggi last accessed 28th Feb 2018.

Kaneva-Johnson, Maria (1994) The Melting Pot: Balkan food and cookery (Totnes: Prospect Books).

Katrandzhiev, Kosta (1940) 'Yoghurt as nutrition and measures for its quality improvement in the capital' in Veterinary Collection 1940: 43-56.

Kostov, Ivan (1998) Made in Bulgaria cannot win against imported goods. Press conference with the Prime Minister of the Republic of Bulgaria at a business meeting on 11 April 1998. Kapital

Newspaper. Available at

https://www.capital.bg/politika_i_ikonomika/bulgaria/1998/04/11/243981_made_in_bulgaria_gubi _sreshtu_vnosnite_stoki/ last accessed 28th Feb 2018.

Law on the labels and geographical indications, Republic of Bulgaria (1999) Official Gazette of the Republic of Bulgaria, Promulgated Vol 81 of 14th Sept 1999, last amended Vol 85 of 24th Oct 2017. Available at https://www.lex.bg/laws/ldoc/2134680576 last accessed 28th Feb 2018.

National Statistical Institute of the Republic of Bulgaria (2016) Population by districts, age, place of residence and sex. Time series Pop.6.1.3_Pop_Dr_En.xls. Available at

http://www.nsi.bg/en/content/6708/population-districts-age-place-residence-and-sex last accessed 28th Feb 2018.

Ranta, Ronald and Nancheva, Nevena (2019). 'Eating Banitza in Post Brexit UK: Integration, Belonging, and the Changing Nature of Bulgarian Foodways' in Food and New Europe Special Issue in Appetite, Editors Zofia Boni, Petra Matijevic. Forthcoming.

Regulation (EU) No 1151/2012 of the European Parliament and of the Council of 21 November 2012 on quality schemes for agricultural products and foodstuffs. OJ L 343, 14.12.2012, p. 1-29.

Roudometoff (2002) Collective Memory, National Identity, and Ethnic Conflict: Greece, Bulgaria and the Macedonian Question (Westport: Praeger Publishers).

Staikov, Ludmil (1988) Time of Violence, film available at https://www.amazon.co.uk/TIMEVIOLENCE-Vreme-razdelno-DVD/dp/B00BHE3TZG last accessed 28th Feb 2018.

Stareva, Liliya (2009) Bulgarian saints and festivals: rituals and prohibitions, divining, fortune telling and magic, weather forecast, ritual objects, foods and symbols (Sofia: Trud).

Stoilova, Elitsa (2014) Producing Bulgarian Yoghurt: manufacturing and exporting authenticity (Amsterdam: Amsterdam University Press).

Stoyanov, Valeri (1998) Turkish population of Bulgaria between the poles of ethnopolitics (Sofia: Lik). In Bulgarian.

Valkanov, Nikolay (2014) Prospects for the milk production livestock in Bulgaria after lifting of quotas in the European Union from 2015. Sofia: Institute for Market Economics. 
Yotova, Maria (2018) 'Ethnographic heritage as a branding strategy: a case study of yogurt in Bulgaria and Japan' in Global Economic Review 47 (1): 47-62.

Yusuke Toyoda, Cihan Erkut, Francisco Pan-Montojo, Sebastian Boland, Martin P. Stewart, Daniel J. Müller, Wolfgang Wurst, Anthony Hyman und Teymuras V. Kurzchalia (2015) Products of the Parkinson's-disease-related glyxolase DJ-1, D-lactate and glycolate, support mitochondrial membrane potential and neuronal survival 